\begin{tabular}{|c|c|c|}
\hline $\bar{\tau}$ & $\begin{array}{l}\text { International Journal of Current Research in } \\
\text { Biosciences and Plant Biology }\end{array}$ & $=$ \\
\hline & Volume 8 • Number 09 (September-2021)• ISSN: 2349-8080 (Online) & \\
\hline $\begin{array}{l}\text { EXCELLENT } \\
\text { PUBLISHERS }\end{array}$ & Journal homepage: $\underline{w w w . i j c r b p . c o m}$ & \\
\hline
\end{tabular}

Original Research Article

doi: https://doi.org/10.20546/ijcrbp.2021.809.002

\title{
Effects of phosphorus, indolebutyric acid and naphthylphthalamic acid on the lateral root growth of Poncirus trifoliata
}

\author{
Tian-zhi Gong and De-jian Zhang (iD)*
}

Yangtze University, College of Horticulture and Gardening, Jingzhou, Hubei 434020, China

*Corresponding author; e-mail: zhangdejian0553@126.com

\begin{tabular}{ll}
\hline Article Info & Abstract \\
\hline Keywords: & To explore the influence of phosphorus (P), indolebutyric acid (IBA, Auxin) and Naphthylphthalamic \\
Indolebutyric acid & $\begin{array}{l}\text { acid (NPA, Auxin transport inhibitor) on plant lateral root (LR) formation, Poncirus trifoliata } \\
\text { Lateral root }\end{array}$ \\
$\begin{array}{l}\text { saphthylphthalamic } \\
\text { acid }\end{array}$ & $\begin{array}{l}\text { NPA, and the regulative effects of P level, IBA and NPA on LR formation of trifoliate orange were } \\
\text { investigated. The results showed that LP level significantly reduced the plant biomass, LR number and }\end{array}$ \\
Phosphorus & $\begin{array}{l}\text { length. NPA significantly decreased the plant biomass, LR number and length, while IBA did not } \\
\text { significantly influence these parameters. These data suggested that auxin signaling pathway could be } \\
\text { involved in the regulation of P level on LR formation, and the auxin transportation should be the key } \\
\text { factor in LR formation of trifoliate orange. }\end{array}$
\end{tabular}

- Received: 21 July 2021 • Revised: 29 August 2021 • Accepted: 01 September 2021 • Published Online: 6 September 2021

\section{Introduction}

Lateral roots are an important component of plant root morphology, and root architecture is largely determined by the length, branching angle and number of lateral roots (Nibau et al., 2008). Lateral root development is influenced by many factors, including biological and abiotic factors (Gruber et al., 2011). Phosphorus was involved in the regulation of lateral root formation, and low phosphorus stress inhibited the increase of the number and length of lateral roots in Zea mays maize (Li et al., 2012). Phosphorus increased lateral root density and number of lateral roots in the shallow root system of Lupinus albus (Péret et al., 2014).

Auxin plays an important role in plant development and is an important internal factor regulating lateral root formation (Fukaki and Tasaka, 2009; Lavenus et al., 2013). Activation of pericysts that form the lateral root primordia is dependent on the accumulation of auxin, with a peak of auxin at the site of lateral root occurrence during subsequent lateral root protrusion and elongation (Nibau et al., 2008). The addition of low concentration exogenous NAA significantly increased the number of lateral roots of white clover Trifolium repens cuts, while the addition of auxin transport inhibitors decreased the number of lateral roots (Dinh et al., 2012). Lateral root formation is highly plasticity and complex and is affected by a variety of environmental conditions. However, the regulation model of phosphorus level on lateral root formation and its differences, as well as the role of auxin in the regulation are not clear, and most 
studies are based on herbaceous plants, and few studies are based on woody plants.

In this study, phosphorus and exogenous auxin were applied to regulate the formation of lateral roots of Poncirus trifoliata seedlings, so as to explore the regulation mode and differences of two factors on the formation of lateral roots.

\section{Materials and methods}

\section{Materials}

Poncirus trifoliata seeds are purchased from the market. The experimental substrate was red soil and river sand mixed at a volume ratio of 1:1. The basic physicochemical properties of red soil were as follows: $\mathrm{pH} 4.60$ and organic matter. The contents were $1.58 \%$, alkali-hydrolyzable nitrogen $66.1 \mathrm{mg} \mathrm{kg}^{-1}$, available phosphorus $22.2 \mathrm{mg} \mathrm{kg}^{-1}$ and available potassium 56.8 $\mathrm{mg} \mathrm{kg}^{-1}$.

The container was a plastic flowerpot (opening width 12 $\mathrm{cm}$, height $14 \mathrm{~cm}$ ). The red soil and river sand were sterilized by wet heat for $2 \mathrm{~h}\left(121^{\circ} \mathrm{C}, 1.8 \mathrm{kPa}\right.$, twice, $1 \mathrm{~h}$ each time), each basin was filled with $700 \mathrm{~g}$. Immaturus aurantii seeds were disinfected with $70 \%$ alcohol surface for $20 \mathrm{~min}$, and then washed clean with sterile single steam water. The seeds were accelerated to sprout in sterile peat. When the plant height was $3-4 \mathrm{~cm}$, the seeds were transplanted with 1 plant in each pot.

\section{Methods}

A two-factor randomized block design was used, and the two-factor was phosphorus level (low phosphorus LP and high phosphorus HP) and auxin (auxin treated
IBA, auxin transport inhibitor treated NPA, control CK).

Pot each with $200 \mathrm{mg} \mathrm{kg}^{-1} \mathrm{~N}$ and $50 \mathrm{mg} \mathrm{kg}^{-1} \mathrm{~K}$. In addition to the phosphorus nutrition of the substrate itself, different amounts of phosphorus were added to maintain different phosphorus concentrations in the substrate, and $20 \mathrm{mg} \mathrm{kg}^{-1} \mathrm{P}$ and $50 \mathrm{mg} \mathrm{kg}^{-1} \mathrm{P}$ were added in the low and high $\mathrm{P}$ treatments, respectively.

The experiment was carried out on March 10, 2020 in a greenhouse under natural light and at $24-30{ }^{\circ} \mathrm{C}$ on July 10, 2020. Each treatment was repeated for 5 times, and samples were collected 4 months after transplanting. The measured indexes included biomass, taproot length, first-grade lateral root length, and the number of lateral roots at each grade.

Data were mean values of 5 repeats. Microsoft Excel software was used to draw the graph, and SAS (6.0) software was used to conduct variance analysis and significance test $(\mathrm{P}<0.05)$.

\section{Results}

\section{Effects of different factors on Poncirus trifoliata seedling growth}

The effects of each treatment on biomass and rootshoot ratio were shown in Table 1. Auxin treatments significantly affected the biomass and root-shoot ratio of Poncirus trifoliata, which is that NPA significantly inhibited the biomass and root-shoot ratio of Poncirus trifoliata, while IBA had no significant effect on these two indexes. Furthermore, LP level had negative effect on biomass and root-shoot ratio, compare that with CK.

Table 1. The influence of $\mathrm{P}$ and auxin on the growth of Poncirus trifoliata seedlings.

\begin{tabular}{llll}
\hline \multicolumn{1}{l}{ Treatments } & & Biomass $(\mathrm{g})$ & Root-shoot ratio \\
\hline CK & & $2.1 \pm 0.2 \mathrm{a}$ & $1.2 \pm 0.1 \mathrm{a}$ \\
CK & IBA & $2.0 \pm 0.1 \mathrm{a}$ & $1.2 \pm 0.1 \mathrm{a}$ \\
& NPA & $1.5 \pm 0.1 \mathrm{c}$ & $0.9 \pm 0.1 \mathrm{~b}$ \\
LP & IBA & $1.8 \pm 0.2 \mathrm{~b}$ & $1.0 \pm 0.1 \mathrm{~b}$ \\
& NPA & $1.0 \pm 0.1 \mathrm{~d}$ & $0.7 \pm 0.1 \mathrm{c}$ \\
\hline
\end{tabular}

Note: Data (means \pm SD,$n=5$ ) followed by different letters indicate significant differences (LSD, $p<0.05$ ) among treatments.

\section{Effects of Different Factors on root length of Poncirus trifoliata Seedling}

The effect of each treatment on root length was shown in Table 2. Auxin treatments significantly affected the tap root and lateral root length of Poncirus trifoliata, which is that NPA significantly induce the tap root and lateral root length of Poncirus trifoliata, while IBA increased it. Furthermore, LP level had negative effect on the tap root and lateral root length. 


\section{Effects of Different Factors on lateral root number of Poncirus trifoliata Seedling}

The effect of each treatment on lateral root number was shown in Table 3 . Auxin treatments significantly affected the number of primary and secondary lateral roots of Poncirus trifoliata, which is that NPA significantly induce the tap root and lateral root length of Poncirus trifoliata, while IBA increased it. Furthermore, LP level had negative effect on the tap root and lateral root length.

Table 2. The influence of $P$ and auxin on the root length of Poncirus trifoliata seedlings.

\begin{tabular}{llll}
\hline Treatments & & Tap root length $(\mathbf{c m})$ & Lateral root length $(\mathbf{c m})$ \\
\hline CK & $10.8 \pm 1.1 \mathrm{~b}$ & $6.1 \pm 0.5 \mathrm{~b}$ \\
CK & IBA & $11.2 \pm 1.2 \mathrm{a}$ & $7.2 \pm 0.7 \mathrm{a}$ \\
& NPA & $8.5 \pm 0.7 \mathrm{c}$ & $5.9 \pm 0.3 \mathrm{~b}$ \\
LP & IBA & $9.8 \pm 0.8 \mathrm{c}$ & $5.8 \pm 0.2 \mathrm{~b}$ \\
& NPA & $7.0 \pm 0.3 \mathrm{~d}$ & $4.7 \pm 0.3 \mathrm{c}$ \\
\hline
\end{tabular}

Note: Data (means $\pm \mathrm{SD}, \mathrm{n}=5$ ) followed by different letters indicate significant differences $(\mathrm{LSD}, \mathrm{p}<0.05)$ among treatments.

Table 3. The influence of $\mathrm{P}$ and auxin on lateral root number of Poncirus trifoliata seedlings.

\begin{tabular}{llll}
\hline Treatments & & Primary lateral roots (no.) & Secondary lateral roots (no.) \\
\hline CK & & $31.2 \pm 2.1 \mathrm{~b}$ & $102.3 \pm 9.5 \mathrm{~b}$ \\
CK & IBA & $35.4 \pm 3.2 \mathrm{a}$ & $120.2 \pm 10.7 \mathrm{a}$ \\
& NPA & $25.5 \pm 2.7 \mathrm{c}$ & $100.9 \pm 8.3 \mathrm{~b}$ \\
LP & IBA & $24.9 \pm 2.9 \mathrm{c}$ & $98.8 \pm 8.2 \mathrm{~b}$ \\
& NPA & $20.1 \pm 1.9 \mathrm{~d}$ & $90.7 \pm 7.9 \mathrm{c}$ \\
\hline
\end{tabular}

Note: Data (means $\pm \mathrm{SD}, \mathrm{n}=5$ ) followed by different letters indicate significant differences (LSD, $\mathrm{p}<0.05)$ among treatments.

\section{Discussion}

The Auxin can affect the growth and development of plants in many aspects. In particular, auxin can promote the formation of lateral roots by activating pericyst cells in roots and thus cause the change of root architecture (Teale et al., 2006). The formation of lateral roots was concentration dependent on auxin. Low concentration promoted the increase of the number and length of lateral roots, while high concentration inhibited them (Dinh et al., 2012; Mayzlish-Gati et al., 2012). In addition, application of auxin transport inhibitors can significantly reduce the number and density of lateral roots (De Dorlodot et al., 2007). In this experiment, 10 $\mathrm{mg} \mathrm{kg}^{-1}$ NPA significantly reduced the number and length of lateral roots while $20 \mathrm{mg} \mathrm{kg}^{-1}$ IBA observably increased its, indicating that NPA could effectively reduce auxin transport, inhibit the formation of lateral roots and reduce the number of lateral roots, which revealed the important role of auxin transport and metabolism in the process of lateral root formation.

The regulation mode of low $\mathrm{P}$ on lateral root formation in plants is controlled by genetics, and the effects of low $\mathrm{P}$ on different plants are not consistent. Low phosphorus induced an increase in the number of lateral roots in Arabidopsis thaliana (Mayzlish-Gati et al., 2012). However, some studies indicated that low $\mathrm{P}$ treatment increased the number of lateral roots in the short term and had significant inhibitory effects on various root indexes over time (Nacry et al., 2005). It has also been reported that low phosphorus treatment reduced the number of lateral roots of maize $(\mathrm{Li}$ et al., 2012). In this experiment, $P$ level had a significant effect on each index. Specifically, low $\mathrm{P}$ reduced the biomass, root-shoot ratio, root length and number of Poncirus trifoliata, which also showed that $\mathrm{P}$ played an important role in plant growth.

\section{Conclusions}

Auxin signaling pathway could be involved in the regulation of $\mathrm{P}$ level on LR formation, and the auxin transportation should be the key factor in LR formation of Poncirus trifoliata. Phosphorus is the environmental factor regulating the formation of lateral roots, while auxin is the internal factor affecting the formation of lateral roots. In addition, auxin was involved in the regulation of phosphorus on lateral root formation. 


\section{Conflict of interest statement}

Authors declare that they have no conflict of interest.

\section{References}

De Dorlodot, S., Forster, B., Pagès, L., Price, A., Tuberosa, R., Draye. X., 2007. Root system architecture: opportunities and constraints for genetic improvement of crops. Trends Plant Sci., 12(10): 474-481.

Dinh, P. T. Y., Roldan, M., Leung, S., McManus, M. T., 2012. Regulation of root growth by auxin and ethylene is influenced by phosphate supply in white clover (Trifolium repens L.). Plant Growth Regul., 66(2): 179-190.

Fukaki, H., Tasaka, M., 2009. Hormone interactions during lateral root formation. Plant Mol. Biol., 69(4): 437-449.

Gruber, V., Zahaf, O., Diet, A., de Zélicourt, A., de Lorenzo, L., Crespi, M., 2011. Impact of the environment on root architecture in dicotyledoneous plants. In: de Oliveira, A. C., Varshney, R. K. (Eds.), Root Genomics. Berlin: Springer Berlin Heidelberg, pp. 113-132.

Lavenus, J., Goh, T., Roberts, I., Guyomarc, S., Lucas, M., De Smet, I., Laplaze, L., 2013. Lateral root development in Arabidopsis: fifty shades of auxin.
Trends Plant Sci., 18(8): 450-458.

Li, Z., Xu, C., Li, K., Yan, S., Qu, X., Zhang, J., 2012. Phosphate starvation of maize inhibits lateral root formation and alters gene expression in the lateral root primordium zone. BMC Plant Biol., 12(1): 89.

Mayzlish-Gati, E., De-Cuyper, C., Goormachtig, S., Beeckman, T., Vuylsteke, M., Brewer, P. B., Wininger, S., 2012. Strigolactones are involved in root response to low phosphate conditions in Arabidopsis. Plant Physiol., 160(3): 1329-1341.

Nacry, P., Canivenc, G., Muller, B., Azmi, A., Van Onckelen, H., Rossignol, M., Doumas, P., 2005. A role for auxin edistribution in the responses of the root system architecture to phosphate starvation in Arabidopsis. Plant Physiol., 138(4): 2061-2074.

Nibau, C., Gibbs, D. J., Coates, J. C., 2008. Branching out in new directions: the control of root architecture by lateral root formation. New Phytol., 179(3): 595-614.

Péret, B., Desnos, T., Jost, R., Jost, R., Kanno, S., Berkowitz, O., Nussaume, L., 2014. Root architecture responses: in search of phosphate. Plant Physiol., 166(4): 1713-1723.

Teale, W. D., Paponov, I. A., Palme, K., 2006. Auxin in action: signaling, transport and the control of plant growth and development. Nat. Rev. Mol. Cell Biol., 7(11): 847-859.

\section{How to cite this article:}

Gong, T. Z., and Zhang, D.J., 2021. Effects of phosphorus, indolebutyric acid and naphthylphthalamic acid on the lateral root growth of Poncirus trifoliata. Int. J. Curr. Res. Biosci. Plant Biol., 8(9): 13-16.

doi: https://doi.org/10.20546/ijcrbp.2021.809.002 